\title{
COMPARING STREAM INVERTEBRATE ASSEMBLAGES BEFORE AND AFTER WILDFIRE IN YELlOWSTONE NATIONAL PARK
}

\author{
P \\ LUSHA M. TRONSTAD $\uparrow$ J. CODY BISH $\uparrow$ ROBERT O. HALL \\ UNIVERSITY OF WYOMING $\uparrow$ LARAMIE \\ TODD M. KOEL $\uparrow$ YELLOWSTONE NATIONAL PARK $\downarrow$ MAMMOTH
}

\begin{abstract}
Warmer, dryer climate conditions during the past three decades are thought to have increased severe fires in the western United States. Severe fires may change food webs due to altered light levels, nutrient concentrations, and hydrology in streams. To measure how wildfire changes stream food webs, we collected aquatic invertebrates before and after a fire, and calculated their density and biomass. To investigate the effects of wildfire on streams, we collected aquatic invertebrates from Cub and Little Cub Creeks on the east side of Yellowstone Lake before and after the East Fire. The timing of our study was serendipitous with the fire burning after our first year of collecting samples. Therefore, we collected one year of data prior to the wildfire (2003) and 2 years of data after the fire (2004 and 2005). The East Fire was a crown fire that set ablaze $>17,000$ acres and burned $\geq 95 \%$ of the watersheds of these streams. Working in Yellowstone National Park is opportune, because few other perturbations exist and the effects of wildfire can be easily studied. We analyzed the samples to understand how wildfire alters stream invertebrates. Our specific questions were: 1) What affect did wildfire have on the density and biomass of aquatic invertebrates? 2) How did the composition of aquatic invertebrates change before and after wildfire? Results from our study will inform managers about how the food base for fish and many birds (i.e., aquatic invertebrates) changes after wildfire.
\end{abstract}

\section{$\downarrow$ INTRODUCTION}

Warmer, dryer climatic conditions during the past 30 years have been attributed to increases in severe, stand-replacing fires in the western US (Westerling et al. 2006). The 1988 fires in Yellowstone National Park are an example of large, severe, stand replacing fires. Severe fires continue to burn in Yellowstone National Park in recent years, where thousands of hectares of forest were consumed. These stand-replacing fires remove the forest canopy and begin new successional trajectories that persist for decades (Turner et al. 2003). In addition, a shift in dominant species, along with the creation of abundant bare mineral soil can often increase the inputs of important nutrients such as nitrogen into adjacent streams and lakes (e.g., Gresswell 1999), similar to Likens et al. (1970) who discovered large pulses of nutrients exported from watersheds after clear-cutting a forest. Turner et al. (2007) studied terrestrial N cycling in Yellowstone and Teton National Parks after fire and noted that $\mathrm{N}$ uptake switch from microbes to plants as succession proceeded. Turner et al. (2007) and climate predictions have prompted us to further investigate how fire will alter aquatic invertebrates in burned watersheds.

Stream food webs may change after wildfire due to altered light levels, nutrient concentrations, and hydrology. Forest canopies open after wildfire increasing light levels that reach streams. Higher light levels along with higher nutrient concentrations increase primary production (e.g., algae) in streams (Mihuc 2004). Higher primary production may cause 
bottom-up effects in streams and subsequently change the aquatic invertebrates and fish in these ecosystems. However, changes in hydrology may limit algal, invertebrate, and fish growth (Minshall et al. 2001a). Water levels can change rapidly in burned watersheds, because of the lack of terrestrial vegetation as a buffer. Thus, floods can scour streams in burned watersheds removing algae and invertebrates. Bottom up effects and hydrology may change the energy flux to higher trophic levels, but little is known about the effects of fire on aquatic food webs (Minshall 2003). However, Perry et al. (2003) discovered that wildfire limited the invertebrates available to juvenile Chinook salmon (Oncorhynchus tshawytscha) in streams in Yukon Territory, Canada.

To investigate the effects of wildfire on streams, we collected aquatic invertebrates from $\mathrm{Cub}$ and Little Cub Creeks on the east side of Yellowstone Lake before and after the East Fire. Many studies of wildfire compare a burned stream with a reference stream (Minshall et al. 2001b), because collecting samples prior to a wildfire is by chance. Thus, having samples before and after fire will improve our knowledge of the effects of wildfire on stream invertebrates. The timing of our study was serendipitous with the fire burning after our first year of collecting samples. We collected one year of data prior to the wildfire (2003) and 2 years of data after the fire (2004 and 2005). Therefore, our study design is ideal to estimate the effects of wildfire on stream invertebrates. The East Fire was a crown fire that set ablaze $>17,000$ acres and burned $\geq 95 \%$ of the watersheds of these stream. Working in Yellowstone National Park is opportune, because few other perturbations exist and the effects of wildfire can be easily studied. Our specific questions were: 1) What affect did wildfire have on the density and biomass of aquatic invertebrates? and 2) How did the composition of aquatic invertebrates change before and after wildfire? Results from our study will inform managers about how the food base for fish (i.e., aquatic invertebrates) changes after wildfire.
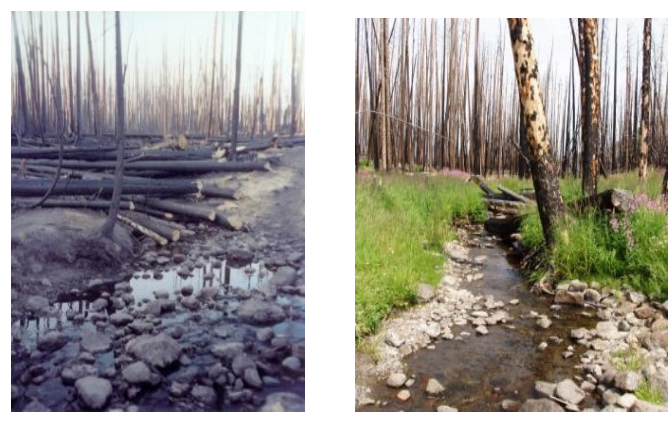

Figure 1. Photos of Little Cub Creek before and after the wildfire.

\section{METHODS}

We collected samples in Cub and Little Cub Creeks (Figure 1), which are tributaries on the east side of Yellowstone Lake, Yellowstone National Park, Wyoming. Cub Creek is a third order stream that is $11.8 \mathrm{~km}$ in length and originates in the Absaroka Range near Jones Pass. The 2180 ha Cub Creek watershed was dominated by lodgepole pine (Pinus contorta), whitebark pine (Pinus albicaulis), and subalpine fire (Abies lasiocarpa) and the bedrock was mostly andesite and rhyolite. Little Cub Creek is a first order stream that is $3.0 \mathrm{~km}$ in length. The 458 ha watershed is dominated by lodgepole pine. Lightning ignited the East Fire which was discovered on 11 August 2003. The crown fire burned 9510 hectares including $95 \%$ of the Cub Creek watershed and $100 \%$ of the Little Cub watershed.

To estimate how the hydrograph compared among years, we measured discharge during each visit to the streams in 2003 to 2005 . We measured discharge using the current meter method (Gore 1996). We calculated the average daily discharge by integrating under the curve and dividing by the total number of days in the period.

We collected aquatic invertebrate samples from $\mathrm{Cub}$ and Little Cub Creeks located on the east side of Yellowstone Lake, Yellowstone National Park. Six Hess samples $\left(0.086 \mathrm{~m}^{2}\right)$ were collected in each stream every 2-4 weeks during the summers of 2003 to 2005 . We preserved invertebrates in $70 \%$ ethanol. We identified aquatic invertebrates using a dissecting microscope, (Merritt et al. 2008; Thorp and Covich 2010). We calculated biomass by measuring the first 20 individuals of each taxon and converting lengths to biomass using published regressions (Benke et al. 1999). We calculated the number of taxa in the orders Ephemeroptera, Plecoptera, and Trichoptera (EPT), which is a simple diversity index of taxa that are generally sensitive to water quality. Finally, we calculated the density of functional feeding groups using Merritt et al. (2008). We called insects with more than one main feeding method generalists.

\section{$\downarrow \quad$ PRELIMINARY RESUltS}

The hydrograph at Cub Creek was less predictable after the fire. In 2003, discharge at Cub Creek decreased throughout the summer. After the watershed burned, discharge displayed a different pattern. On 18 July 2004, a large flood occurred after a rain storm, which scoured and rearranged the 
stream. We observed that discharge rose after most rain storms during the summers of 2004 and 2005. Average daily discharge was $>2 \mathrm{x}$ higher after wildfire (66 and $53 \mathrm{~m}^{3} / \mathrm{s}$ in 2004 and 2005 respectively) monitored before fire $\left(26 \mathrm{~m}^{3} / \mathrm{s}\right)$ when compared in June through October (Figure 2). Unfortunately, we did not measure discharge in Little Cub Creek before the fire; however, mean daily discharge in Little Cub Creek was lower in $2004\left(0.046 \mathrm{~m}^{3} / \mathrm{sec}\right)$ than 2005 $\left(0.094 \mathrm{~m}^{3} / \mathrm{sec}\right)$ between May and July.
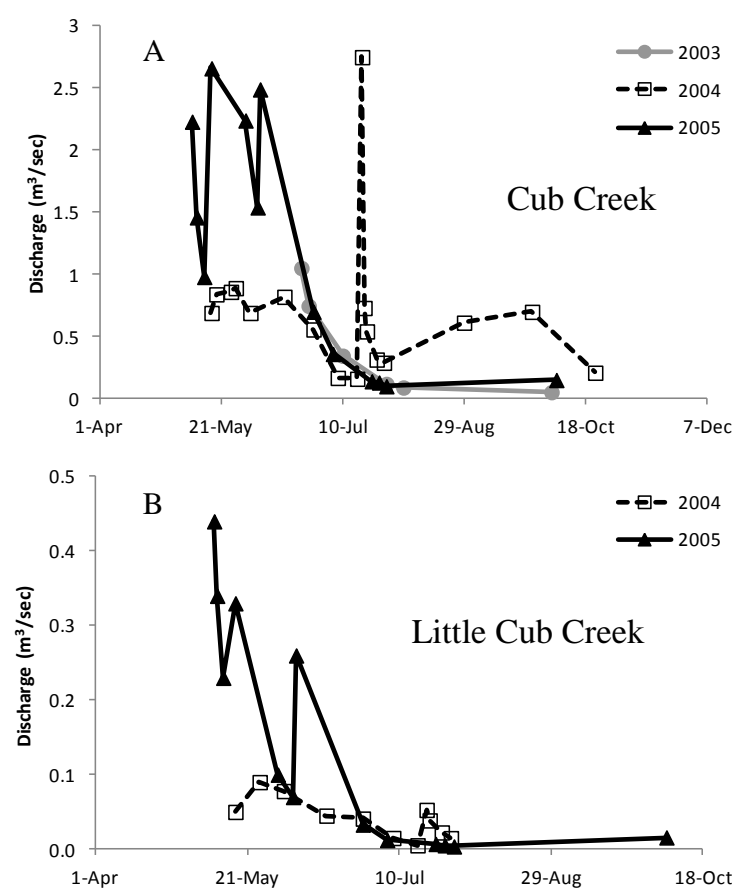

Figure 2. Summer discharge in Cub Creek (A) and Little Cub Creek (B) before (2003) and after the wildfire (2004 and 2005).

In Cub Creek, we collected 34 invertebrate taxa of which 31 were insects from 6 orders (Figure 3 ). Diptera were the most abundant order of insects in the stream, followed by Ephemeroptera and Plecoptera. On average, we collected 11 (range 1-20) taxa in each sample. Total invertebrate density was similar the summer before $\left(1000 \mathrm{ind} / \mathrm{m}^{2}\right)$ and after wildfire $\left(1200 \mathrm{ind} / \mathrm{m}^{2}\right)$, but total density was over two times higher 2 years after wildfire $\left(2600 \mathrm{ind} / \mathrm{m}^{2}\right.$; ANOVA, $\mathrm{P}=0.014$, df $=2, \mathrm{~F}=4.42$ ). Finally, the number of taxa and EPT were similar among years (ANOVA, $\mathrm{P}=0.59$, $\mathrm{df}=2, \mathrm{~F}=0.53$ and $\mathrm{P}=0.82$, $\mathrm{df}$ $=2, \mathrm{~F}=0.20$, respectively).

Diptera density increased by $>3 x$ after wildfire $\left(1450 \mathrm{ind} / \mathrm{m}^{2}\right)$ compared to pre-fire estimates (400 ind $/ \mathrm{m}^{2}$; ANOVA, $\mathrm{P}=0.0048$, df $=2, \mathrm{~F}=5.65$; Figure 3). Chironomidae were the most abundant family of true flies (Diptera). The density of both
non-Tanypodinae (1250 ind $\left./ \mathrm{m}^{2}\right)$ and Tanypodinae (predaceous; $82 \mathrm{ind} / \mathrm{m}^{2}$ ) Chironomidae increased $3 \mathrm{x}$ and $5 \mathrm{x}$ respectively compared to pre-fire estimates $\left(350 \mathrm{ind} / \mathrm{m}^{2}\right.$; ANOVA, $\mathrm{P}=0.011$, $\mathrm{df}=2, \mathrm{~F}=4.75$ and $13 \mathrm{ind} / \mathrm{m}^{2}$; ANOVA, $\mathrm{P}=0.18$, df $=2, \mathrm{~F}=1.75$, respectively).

Total Ephemeroptera density was similar among years (ANOVA, $\mathrm{P}=0.22$, df $=2, \mathrm{~F}=1.50$; Figure 3). Several taxa of mayflies increased after wildfire, such as Rithrogena (50 v. $250 \mathrm{ind} / \mathrm{m}^{2}$; ANOVA, $\mathrm{P}=0.15$, $\mathrm{df}=2, \mathrm{~F}=1.95)$, Drunnela doddsi (13 vs. $83 \mathrm{ind} / \mathrm{m}^{2}$; ANOVA, $\mathrm{P}=0.0008$, df $=$ $2, \mathrm{~F}=7.6$ ), and Serratella (3 vs. $45 \mathrm{ind} / \mathrm{m}^{2}$ ANOVA, $\mathrm{P}=0.0002$, $\mathrm{df}=2, \mathrm{~F}=9.5)$. In contrast, the density of Cinygma decreased after wildfire ( 7.6 vs. $0 \mathrm{ind} / \mathrm{m}^{2}$; ANOVA, $\mathrm{P}=0.02$, $\mathrm{df}=2, \mathrm{~F}=4.1$ ). Finally, several genera increased in density immediately after wildfire and then decreased to pre-fire density 2 years after fire, such as Cinygmula, Epeorus, and Plauditus.

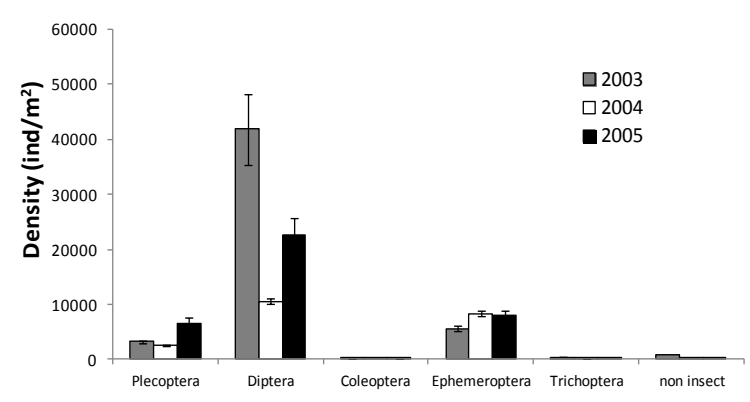

Figure 3. Density of aquatic insect orders in Cub Creek before (2003) and after (2004 and 2005) wildfire.

Total Plecoptera density nearly doubled 2 years after the fire $\left(240 \mathrm{ind} / \mathrm{m}^{2}\right.$ in 2003 and $2004 \mathrm{vs.}$ $570 \mathrm{ind} / \mathrm{m}^{2}$ 2005; ANOVA, $\mathrm{P}=0.069$, df $=2, \mathrm{~F}=$ 2.75 (Figure 3). The most abundant Plecoptera genera were Sweltsa and Suwallia (family Chloroperlidae). Sweltsa density increased 2 years after the fire $\left(470 \mathrm{ind} / \mathrm{m}^{2}\right)$, but the flood in 2004 probably reduced density $\left(130 \mathrm{ind} / \mathrm{m}^{2}\right)$ compared to pre-fire numbers $\left(250 \mathrm{ind} / \mathrm{m}^{2}\right.$; ANOVA, $\mathrm{P}=0.064$, df $=2, \mathrm{~F}=2.83)$. Conversely, Suwallia density (45 ind $/ \mathrm{m}^{2}$ ) was lower after the fire in 2004 (30 ind $/ \mathrm{m}^{2}$ ) and 2005 (10 ind $/ \mathrm{m}^{2}$; ANOVA, $\mathrm{P}=0.091$, $\mathrm{df}=2, \mathrm{~F}=$ 2.46).

Trichoptera density decreased after wildfire (30 ind $/ \mathrm{m}^{2}$ in 2003 vs. $12 \mathrm{ind} / \mathrm{m}^{2}$ in 2004 and 2005; ANOVA, $\mathrm{P}=0.0007$, $\mathrm{df}=2, \mathrm{~F}=7.81$; Figure 3 ). The density of both Glossosoma (18 vs. 3 ind $/ \mathrm{m}^{2}$; ANOVA, $\mathrm{P}=0.0001, \mathrm{df}=2, \mathrm{~F}=10.1)$, and Rhyacophila (12 vs. 6 ind $/ \mathrm{m}^{2}$; ANOVA, $\mathrm{P}=0.23$, df $=2, \mathrm{~F}=1.5)$, decreased after wildfire. 
The dominant functional feeding groups were the same before and after fire. Generalists were the most abundant group before and after the fire and their density increased after fire $\left(530 \mathrm{ind} / \mathrm{m}^{2}\right.$ in 2004 and $1300 \mathrm{ind} / \mathrm{m}^{2}$ in 2005) compared to pre-fire conditions $\left(370 \mathrm{ind} / \mathrm{m}^{2}\right.$; ANOVA, $\mathrm{P}=0.007$, df $=2 . \mathrm{F}$ $=5.3$; Figure 4$)$. Compared to pre-fire densities $(350$ $\left.\mathrm{ind} / \mathrm{m}^{2}\right)$, predators initially decreased in 2004 (220 ind $/ \mathrm{m}^{2}$ ), but nearly double in density in 2005 (660 $\mathrm{ind} / \mathrm{m}^{2}$; ANOVA, $\mathrm{P}=0.07$, $\mathrm{df}=2, \mathrm{~F}=2.6$ ). Scrapers, the third most abundant group, had similar densities before and immediately after fire $\left(215 \mathrm{ind} / \mathrm{m}^{2}\right.$ in 2003 and $250 \mathrm{ind} / \mathrm{m}^{2}$ in 2004), but they increased 2 years after fire (400 ind $/ \mathrm{m}^{2}$; ANOVA, $\mathrm{P}=0.31$, df $=2, \mathrm{~F}=$ 1.2). The density of collector-gatherers increased after fire (145 ind $/ \mathrm{m}^{2}$ in 2004 and $125 \mathrm{ind} / \mathrm{m}^{2}$ in 2005) compared to pre-fire $\left(45 \mathrm{ind} / \mathrm{m}^{2}\right.$; ANOVA, $\mathrm{P}=$ 0.01 , df $=2, F=4.5)$. Shredders increased in density (30 ind $/ \mathrm{m}^{2}$ in 2004 and $100 \mathrm{ind} / \mathrm{m}^{2}$ in 2005) compared to pre-fire densities $\left(8 \mathrm{ind} / \mathrm{m}^{2}\right.$; ANOVA, $\mathrm{P}$ $=0.01$, df $=2, F=4.6)$. Finally, filterers, the least abundant group, had similar densities before (1 $\left.\mathrm{ind} / \mathrm{m}^{2}\right)$ and after fire $\left(2-3 \mathrm{ind} / \mathrm{m}^{2}\right.$; ANOVA, $\mathrm{P}=0.7$, $\mathrm{df}=2 ; \mathrm{F}=0.3)$.

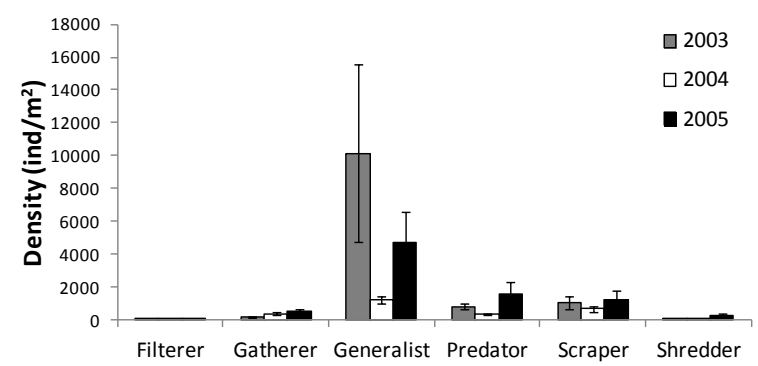

Figure 4. Density of aquatic invertebrates by their functional feeding groups before (2003) and after (2004 and 2005) the wildfire in Cub Creek.

We collected 42 invertebrate taxa in Little Cub Creek of which 37 taxa were insects in 5 orders (Figure 5). Diptera were the most abundant order of insects followed by Coleoptera, Plecoptera, Ephemeroptera, and Trichoptera. On average, we collected 13 taxa per sample (range 5-21). Total invertebrate density was lower before wildfire (5800 $\left.\mathrm{ind} / \mathrm{m}^{2}\right)$ compared to $2004\left(11,300 \mathrm{ind} / \mathrm{m}^{2}\right)$ and 2005 $\left(10,900 \mathrm{ind} / \mathrm{m}^{2}\right.$; ANOVA, $\left.\mathrm{P}=0.04, \mathrm{df}=2, \mathrm{~F}=3.1\right)$. On average, more taxa were collected in 2003 (14) compared to 2004 (12) and 2005 (13; ANOVA, P = 0.035 , df $=2, \mathrm{~F}=3.5)$. The most EPT taxa were collected in 2003 (6.9) compared to 2004 (5.3) and 2005 (6.6; ANOVA, $\mathrm{P}=0.038, \mathrm{df}=2, \mathrm{~F}=3.39$ ).

Diptera increased nearly $4 x$ one year after fire $\left(8000 \mathrm{ind} / \mathrm{m}^{2}\right)$ and nearly $3 \mathrm{x}$ two years after fire (5900 ind $/ \mathrm{m}^{2}$ ) compared to pre-fire densities (2400 ind $/ \mathrm{m}^{2}$; ANOVA, $\mathrm{P}=0.0001$, $\left.\mathrm{df}=2, \mathrm{~F}=9.94\right)$ in Little Cub Creek (Figure 5). Similar to Cub Creek, Chironomidae were the most abundant family of Diptera. Non-Tanypodinae Chironomidae were far more abundant than the predaceous Tanypodinae subfamily. Chironomidae increased $>3 \mathrm{x}$ and $>2 \mathrm{x}$ after fire in 2004 and 2005 respectfully (ANOVA, $\mathrm{P}=$ 0.0002 , df $=2, F=9.5)$. Other common Diptera were Tipulidae (Hexatoma, Rhabdomastix, Dicranota, and Tipula), Ceratopogonidae (Probezzia), Simulidae (Simulium), and Ptychopteridae (Ptychoptera).

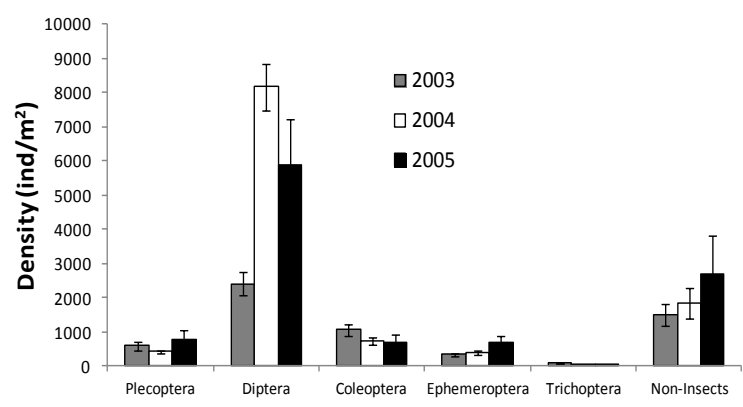

Figure 5. Density of aquatic insect orders in Little Cub Creek before (2003) and after (2004 and 2005) wildfire.

Coleoptera (830 ind $/ \mathrm{m}^{2}$; ANOVA, $\mathrm{P}=0.31$, $\mathrm{df}=2, \mathrm{~F}=1.18)$ and Plecoptera $\left(600 \mathrm{ind} / \mathrm{m}^{2}\right.$; ANOVA, $\mathrm{P}=0.32$, $\mathrm{df}=2, \mathrm{~F}=1.17$ ) densities were similar among years in Little Cub Creek (Figure 5). Heterlimnius (Elmidae) were by far the most abundant beetles we collected (98\% of individuals collected). Sweltsa (Chloroperlidae) were the most abundant stoneflies that we collected $(81 \%$ of individuals collected).

Ephemeroptera densities increased 2 years after fire $\left(700 \mathrm{ind} / \mathrm{m}^{2}\right)$ compared to $2003\left(325 \mathrm{ind} / \mathrm{m}^{2}\right)$ and 2004 (375 ind $/ \mathrm{m}^{2}$; ANOVA, $\mathrm{P}=0.045$, df $=2, \mathrm{~F}$ = 3.2) in Little Cub Creek (Figure 5). Cinygmula (Heptageniidae), Plauditus (Baetidae), Serratella (Ephmerellidae), and Ameletus (Ameletidae) were the most abundant mayfly genera in Little Cub Creek. Cinygmula and Serratella densities were similar among years (ANOVA, $\mathrm{P}>>0.05$ ). In contrast, Plauditus (ANOVA, $\mathrm{P}=0.0015$, df $=2, \mathrm{~F}=7.0$ ) and Ameletus (ANOVA, $\mathrm{P}=0.032$, df $=2, \mathrm{~F}=3.6$ ) densities increased 2 years post-fire.

Similar to Cub Creek, Trichoptera densities decreased post fire in Little Cub Creek (ANOVA, P < 0.0001 , df $=2, F=11$; Figure 5). We collected 2 genera of Trichoptera in Little Cub Creek, Glossosoma (Glossosomatidae) and Rhyacophila (Rhyacophilidae), all of which responded similarly to fire. 
Non-insect invertebrates were much more abundant in Little Cub Creek compared to $\mathrm{Cub}$ Creek. Non-insect invertebrate densities were similar before and after fire $\left(2000 \mathrm{ind} / \mathrm{m}^{2}\right.$; ANOVA, $\mathrm{P}=0.41$, $\mathrm{df}=2 . \mathrm{F}=0.91 ;$ Figure 5$)$. Oligochaeta $(55 \%$ of individuals) and Ostracoda (35\% of individuals) were the most numerous.

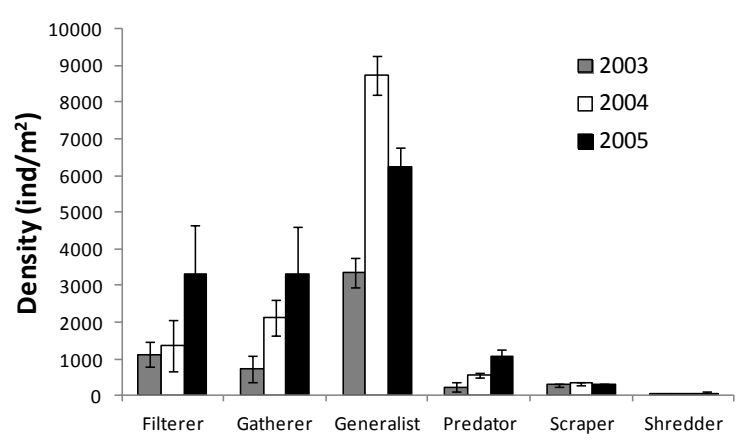

Figure 6. Density of aquatic invertebrates by their functional feeding groups before (2003) and after (2004 and 2005) the wildfire in Little Cub Creek.

The functional feeding groups in Little $\mathrm{Cub}$ Creek were similar before and after fire (Figure 6). Generalists were the most abundant group, following by filterers, gatherers, predators, scrapers, and shredders in decreasing order. Filterers (ANOVA, $\mathrm{P}$ $<0.0001, \mathrm{df}=2, \mathrm{~F}=10.5$ ), generalist (ANOVA, $\mathrm{P}=$ $0.0005, \mathrm{df}=2, \mathrm{~F}=8.3$ ), and shredders (ANOVA, $\mathrm{P}=$ $0.015, \mathrm{df}=2, \mathrm{~F}=4.4$ ) increased in density after the fire. However, the densities of gatherers, predators, and scrapers were similar before and after wildfire (P $>0.05$ ).

The density of aquatic invertebrates not only changed among years, but density changed through time. In general, the density of aquatic invertebrates increased between May and October each year (Figure 7). In general, we measured the highest densities of invertebrates in October. However, the flood that occurred on July $18^{\text {th }} 2004$ reduced the densities of invertebrates in Cub Creek, but we did not observe the same decrease in density in Little Cub Creek. In Little Cub Creek, invertebrate densities increased each year after fire; however, the density of invertebrates in Cub Creek was similar in 2003 and 2005.

Similarly, biomass changed among years and throughout the summer (Figure 8). In general, biomass tends to increase between May and October; however, biomass in Cub Creek remained low after the flood in 2004. We did not observe a decrease in insect biomass after the flood in Little Cub Creek.
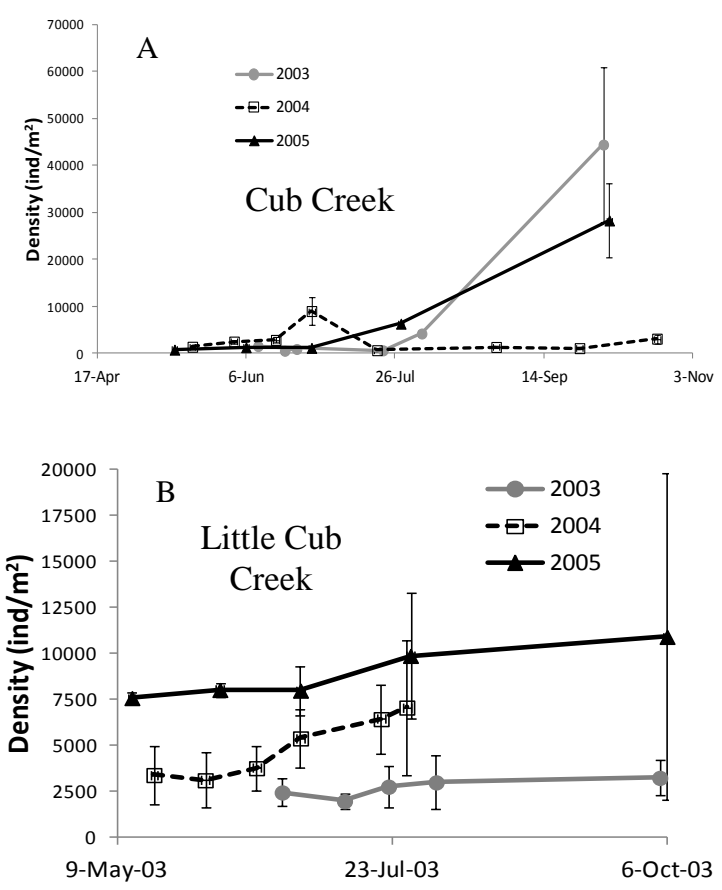

Figure 7. Total invertebrate density in Cub (A) and Little Cub Creeks (B) before (2003) and after (2004 and 2005) wildfire.
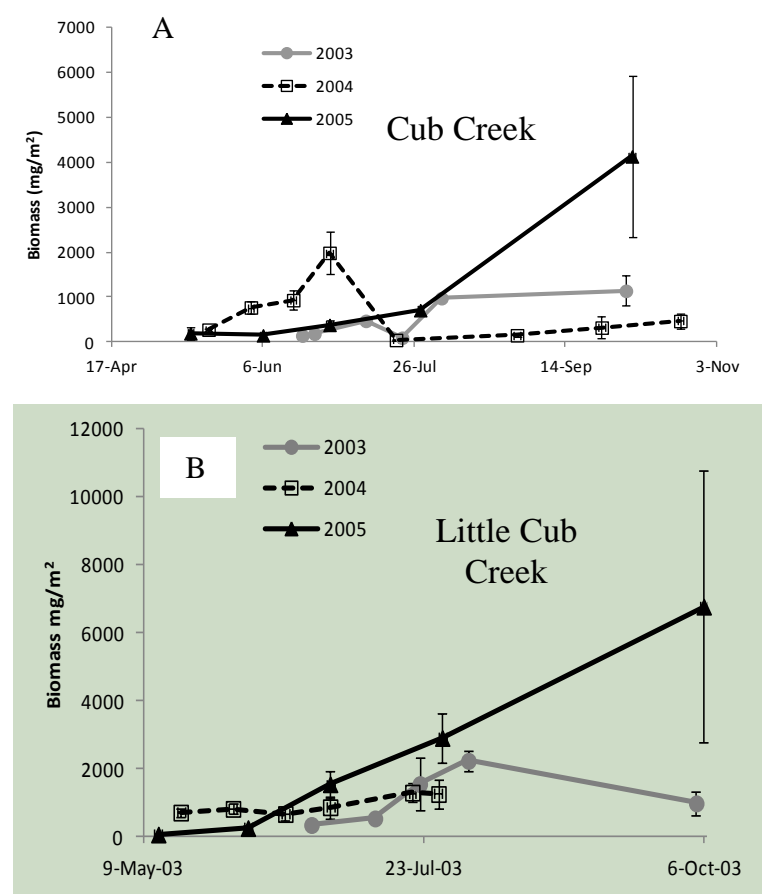

Figure 8. Total invertebrate biomass in Cub (A) and Little Cub Creeks (B) before (2003) and after (2004 and 2005) wildfire. 
Interestingly, we measured a decrease in insect biomass immediately after the fire in Little Cub Creek, but biomass was similar immediately before and after fire in Cub Creek. Biomass in both streams was highest in October of 2005.

\section{$\uparrow \quad$ MANAGEMENT IMPLICATIONS}

Wildfires can greatly change landscapes, ecosystems, communities and population dynamics, but these natural events are unpredictable and difficult to study. Previous studies have investigated the effects of fire by comparing streams in burned watersheds to unburned reference streams (e.g., Minshall et al. 2001a). In our study, we were able to compare pre- and post-fire conditions in the same stream, because a fire unexpectedly burned $\geq 95 \%$ of the watersheds after our first field season.

Several factors likely determine the extent to which stream processes will be affected after wildfire. For example, more severe fires and fires that burn the majority of a watershed tend to have a greater impact on streams (Minshall 2003). In Cub and Little Cub Creeks, most of the watershed was burned by a crown fire, which likely affected the stream to a greater extent. Smaller streams with higher gradients and vegetation cover are also predicted to be affected to a greater degree after fire (Minshall 2003). Cub Creek is a $3^{\text {rd }}$ order stream that drops $51 \mathrm{~m}$ per $\mathrm{km}$ of stream length. Little Cub Creek is a $1^{\text {st }}$ order stream in a forested watershed that drops $35 \mathrm{~m}$ in elevation per $\mathrm{km}$ of stream length. Therefore, the East fire likely had a large effect on processes within Cub and Little Cub Creeks.

Aquatic invertebrates declined immediately after wildfire in Little Cub Creek; however, we did not observe the same trend in Cub Creek. Water has a high specific heat which means that a lot of energy is needed to raise the temperature of the water. Little Cub Creek is a much smaller stream than Cub Creek, thus wildfire probably increased water temperatures to a greater degree in the Little Cub Creek. Biomass of invertebrates declined immediately after wildfire in Little Cub Creek. Conversely, invertebrate densities in Cub Creek were higher compared to before wildfire, which appears to be an annual trend. We did not observe changes to stream invertebrates in Cub Creek until the following summer. Roby and Azuma (1995) found that invertebrate density and richness were lower in burned streams 3 weeks after fire in northern California.
Previous studies reported that aquatic invertebrate densities increased after wildfire (Albin 1979, Roby and Azuma 1995, Gresswell 1999). In Cub Creek, invertebrate densities were initially higher than pre-fire estimates the first summer after wildfire, but a July flood greatly reduced abundance for the rest of the year. However, we estimated that invertebrate densities were higher 2 years after wildfire, similar to other studies. In contrast, Minshall et al. (2001b) noted that density was lower in burned streams compared to reference streams in Idaho. In this stream, densities were likely lower because of scouring and runoff in the stream channel, similar to what we observed in 2004.

Invertebrate richness is reported to decrease in burned compared to reference streams (Gresswell 1999, Roby and Azuma 1995, Minshall et al. 2001b). Roby and Azuma (1995) found that invertebrate richness was lower in burned streams for the 11 years that they collected samples. In contrast, taxa richness was similar in burned and reference streams after 10 years, which may have been caused by lower water levels during drought. We did not detect a change in taxa richness during the 2 years after fire as the other studies did.

Food sources and invertebrate functional feeding groups are predicted to change after wildfire. Prior to fire, invertebrates primarily use allochthonous inputs (e.g., leaf litter); however, after the vegetation burns and the forest canopy opens invertebrates in streams likely switch to autochthonous sources (i.e., stream algae; Mihuc 2004). Because of these changes in resources, invertebrate functional feeding groups may change. Shredders and collector-gatherers in unburned streams are predicted to be replaced by scrapers and filterers (Minshall et al. 1989, Gresswell 1999). In fact, Minshall et al. (2001b) noted that scrapers and filterers became more abundant after fire. Scrapers likely increased to eat the biofilm that became more abundant in response to higher nutrient concentrations and light. Similarly, the concentration of fine particles in the water may have increased after fire, making an abundant food source for filterers. In contrast to these studies, the dominant functional feeding groups in Cub Creek did not change before and after fire. Collector-gatherers and shredders were some of the least abundant functional feeding groups before and after the wildfire in Cub Creek, whereas scrapers and filterers were the third and least abundant groups. Perhaps the food web in Cub Creek never relied too heavily upon fine particulate organic matter, but biofilm appeared to have been an important food source in Cub Creek before the fire. 
In Little Cub Creek, gatherers and filterers were common before and after wildfire, but scrapers and shredders were never abundant. Many model streams have headwaters in deciduous forest; however, streams in Yellowstone National Park do not have such abundant leaf litter, which may at least partially explain differences compared to other studies.

Wildfire can alter the composition of stream invertebrates. In burned Idaho streams, disturbance adapted insects, such as Baetis and Chironomidae, increased in abundance after wildfire (Minshall et al. 2001b). Similarly, Chironomidae density increased in Cub and Little Cub Creeks after fire. However, the density of more sensitive taxa can decrease after wildfire. For example, Ephemeroptera (Minshall et al. 2001a) and Trichoptera (Albin 1979) densities were lower in burned compared to unburned streams. The density of EPT in Cub and Little Cub Creeks was similar before and after wildfire, but the response varied by order. Therefore, decreased water quality may not have been responsible for changes in composition. Instead, the ability to withstand floods and increased fine sediments may have been at least partially responsible for changes. In Cub Creek, the density of Ephemeroptera with flattened bodies increased in density after wildfire. The body form of these genera may have allowed them to persist through floods and other scouring events that occurred after the fire while other taxa were swept away. Similar to Albin (1979), Trichoptera densities in Cub and Little Cub Creeks decreased after fire. These filter feeders may have been negatively affected by an increase in fine sediments that often occurs after wildfire (Minshall et al. 2001a).

Two opposite forces affect streams after wildfire. First, more nutrients and light typically increase primary production in streams. Increases in in-stream food resources may cause bottom-up effects that increase stream invertebrates and their consumers (e.g., fish). Second, the loss of vegetation and forest on the landscape can alter the hydrology of a watershed. The lack of primary producers can cause variable discharge, scours, and floods. In unburned watersheds, the primary producers slow the movement of water through the watershed creating a slow and decreased release of water through the growing season. In Cub Creek, hydrology controlled the invertebrate assemblage in 2004 by likely reducing biofilm and removing invertebrates. However, bottom-up effects dominated in 2005 when there were no major floods and invertebrate densities were higher.
Fire may also impact fish in burned streams through food web effects. When bottom-up effects predominate in burned streams, more food (i.e., invertebrates) may be available to fish. However, when hydrology dominates burned streams, less food may be available to fish. Yellowstone cutthroat trout (Oncorhynchus clarkii bouvieri) spawn in Cub and Little Cub Creeks for 2 to 3 months each year. Although the adults do not live in these streams, juvenile cutthroat trout rear here. Aquatic invertebrates are likely the dominant food for these young trout. Juvenile cutthroat trout were likely washed out of the stream in 2004 when Cub Creek was scoured; however, these fish may have enjoyed an abundant food source in 2005. High densities of aquatic invertebrates may translate into higher growth rates and ultimately higher survival rates when these fish migrate downstream to Yellowstone Lake.

\section{$\uparrow \quad$ ACKNOWLEDGEMENTS}

We thank Christine Fisher, Christine Smith, and the Fisheries and Aquatic Science crews from 2003-2005 for assistance.

\section{$\uparrow \quad$ LiTERATURE CITED}

Albin DP. 1979. Fire and stream ecology in some Yellowstone Lake tributaries. California Fish and Game. 65:216-238.

Benke AC, Huryn AD, Smock LA, Wallace JB. 1999. Length-mass relationship for freshwater macroinvertebrates in North America with particular reference to the southeastern United States. Journal of the North American Benthological Society. 18:308343.

Gore JA. Discharge measurements and streamflow analysis. In: Hauer FR, Lamberti GA, Editors. Methods in Stream Ecology. New York: Academic Press, Inc.; P 53-74. 1996.

Gresswell RE. 1999. Fire and aquatic ecosystems in forested biomes in North America. Transactions of the American Fisheries Society. 128:193-221.

Likens GE, Bormann FH, Johnson NM, Fisher DW, Pierce RS. 1970. Effects of forest cutting and herbicide treatment on nutrient budgets 
in the Hubbard Brook watershed-ecosystem. Ecological Monographs. 40:24-47.

Merritt RW, Cummins KW, Berg MB. Editors. An Introduction to the Aquatic Insects of North America, 4th edition. Dubuque, IA: Kendall Hunt Publishing. 2008

Mihuc TB. . Food web dynamics in Yellowstone streams: shifts in the trophic basis of a stream food web after wildfire disturbance. In: Wallace L, Editor. After the fires: the ecology of change in Yellowstone National Park. New Haven Yale University Press. 2004. P 89-199.

Minshall GW. 2003. Responses of stream benthic macroinvertebrates to fire. Forest Ecology and Management. 178:155-161.

Minshall GW, Brock JT, Andrews DA, Robinson CT. 2001a. Water quality, substratum and biotic responses of five central Idaho (USA) streams during the first year following the Mortar Creek fire. International Journal of Wildland Fire. 10:185-199.

Minshall GW, Brock JT, Varley JD. 1989. Wildfires and Yellowstone's stream ecosystem. Bioscience. 39:707-715.

Minshall GW, Robinson CT, Lawrence DE, Andrews DA, Brock JT. 2001b. Benthic macroinvertebrate assemblages in five central Idaho (USA) streams over a 10-year period following disturbance by wildfire. International Journal of Wildland Fire. 10:201-213
Perry RW, Bradford MJ, Grout JA. 2003. Effects of disturbance on contribution of energy sources of growth of juvenile chinook salmon (Oncorhynchus tshawytscha) in boreal streams. Canadian Journal of Fisheries and Aquatic Sciences. 60:390-400.

Roby KB, Azuma DL. 1995. Changes in a reach of a northern California stream following wildfire. Environmental Management. 19:591-600.

Thorp JH, Covich AP. Editors. Ecology and Classification of North American Freshwater Invertebrates, 3rd edition. New York: Elsevier; 2010.

Turner MG, Romme WH, Tinker DB. 2003. Surprises and lessons from the 1988 Yellowstone fires. Frontiers In: Ecology and the Environment. 1:351-358.

Turner MG, Smithwick EAH, Metzger KL, Tinker, DB, Romme WH. 2007. Inorganic nitrogen availability after severe stand-replacing fire in the Greater Yellowstone ecosystem. Proceedings of the National Academy of Science. 104:4782-4789.

Westerling AL, Hidalgo HG, Cayan DR, Swetnam TW. 2006. Warming and earlier spring increase western US forest wildfire activity. Science. 313:940-94 